\title{
CORRESPONDENCE
}

\section{Academic Freedom}

SIR,-The Tenth Conference on Slavic Studies with the theme "Croatian Nation and Croatian Exodus-investigation of effects after 100 years of emigration" was held at Case Western Reserve University, Cleveland, Ohio, November 26-28, 1971. The participants and sponsors issued at the conclusion of the conference the following statement:

We deeply regret the last minute changes in circumstances and decisions that prevented the attendance of the scheduled conference speakers from Yugoslavia: Professor Dr Ljudevit Jonke, Croatian University, Zagreb, and President, Matica Hrvatska; Pro- fessor Dr Ivo Baucic, Croatian University, Zagreb; Professor Andjelko Runjic, Croatian University, Zagreb, and Professor Ivan Cizmic, Historical Institute, Matica Iseljnika Hrvatske, Zagreb.

Such occurrences are contrary to generally accepted practice of cultural exchanges intended to further understanding, cooperation and peace in the world.

We believe that academic freedom and international exchange of scholarship should not be infringed upon under any circumstances.

We are, however, confident that exchanges between American scholars in general, and those of Croatian descent in particular, and their colleagues in
Croatia will be frequent and fruitful in the future. TEFKo SARACEVIC

President, American Croatian

Academic Club,

General Chairman of the Conference

VLADIMIR RUS

Chairman, Department of Slavic and

East European Languages,

Case Western Reserve University Michael S. PaP

Director, Institute for Soviet and

East European Studies,

John Carroll University

Dusko I. Duisin

President

Croatian Academy of America

VICTOR KOLUDROVICH

President,

Croatian Foundation of America

\section{Obituary}

\section{Professor G. W. Harris}

THE death of Geoffrey W. Harris, Dr Lee's Professor of Anatomy in the University of Oxford, on November 29, 1971, deprives British endocrinology of a scientist of world stature who did much to clarify the relationships between the brain and endocrine system and so lay the foundations of the subdiscipline of neuroendocrinology. The work which made his name was the discovery of the functional significance of the hypophyseal portal vessels linking the brain and pituitary gland. $\mathrm{He}$ was also deeply involved in the isolation of the chemical agents that control the output of anterior pituitary hormones, the releasing factors.

While a student at Cambridge in 1935 Harris became greatly interested in the work of F. H. A. Marshall, who had drawn attention to the observations establishing that environmental stimuli influence reproductive function in numerous species, and was led to investigate the physiological basis of these effects. Marshall had shown with E. B. Verney that diffuse electrical stimulation of the brain of anaesthetized female rabbits frequently caused ovulation and suggested to Harris that the effects of localized electrical stimulation of the hypothalamus merited study. In due course the demonstration that excitation of the hypothalamus elicited gonadotrophin secretion launched Harris on his life's work.

Since it was then believed that many neuroendocrine responses were slow to become manifest, and that prolonged stimulation of the brain was required to elicit them, Harris devoted much time and ingenuity to developing a method for the inductive stimulation of the brain in freely moving and conscious animals. This was long before the development of radio-controlled devices. Because the generation of massive electromagnetic fields was necessary, the equipment was spectacular in operation, although the rabbits housed in it remained undisturbed. At first, attention was directed toward the activities of the neurohypophysis, the control of milk ejection and uterine motility, but later the control of adrenal and thyroid gland function came under scrutiny.

In parallel with this work the nature of the functional link between the brain and pituitary gland was being determined. Although it was expected that nerve fibres would transmit stimuli from the nervous system to this endocrine organ, the necessary nerve fibres in the anterior pituitary proved extremely difficult to demonstrate convincingly and the possibility that the hypophyseal portal vessels could provide an alternative pathway remained speculative, al- though J. D. Green and Harris had been able to demonstrate that blood flowed from the median eminence to the pituitary gland.

Previous workers had examined the effect of section of the pituitary stalk on the secretion of pituitary hormones with contradictory findings, but Harris in 1950 established that rapid regeneration of the portal vessels occurred after transection and that the level of pituitary function could be related to the degree of vascular reconnexion. Prevention of regeneration of the system by the insertion of a waxed paper plate was associated with a consistent depression of pituitary function.

The special character of the blood derived from the median eminence of the hypothalamus was next established in work with Dora Jacobsohn by removing the pituitary gland of rats and then placing pituitary tissue either in contact with the median eminence or under the temporal lobe of the brain. Only those animals with grafts made to the median eminence showed a return of pituitary function, although in both locations the transplant was nourished by blood vessels derived from the brain. This work also indicated that the cyclic pattern of gonadotrophin secretion seen in the female, as opposed to the constant release in the male, is due to differences in hypothalamic activity. 
As soon as it appeared that neurohumoral agents from the hypothalamus were discharged into the portal vessels for transmission to the anterior lobe of the pituitary to affect the secretion of hormones, experiments aimed at the isolation of these factors began. Harris and his collaborators in 1960 obtained an acidic extract of median eminence tissue that evoked ovulation in the rabbit, but progress in this field proved slow and the identification of this factor eluded them. Quite recently the structure of porcine luteinizing hormone releasing factor was announced by A. V. Schally and his colleagues in New Orleans, an important step towards obtaining a synthetic molecule.

\section{Reports and Publicafions}

not included in the Monthly Books Supplement

\section{Great Britain and Ireland}

Proceedings of the Royal Irish Academy. Vol. 71, Section B, No. 11: The Petrology, Chemistry and Structure of the Galway Granite in the Rosmuc Area, Co. Galway. By C. W. Claxton. Pp. 155-170. 34p. Vol. 71, Section B, No. 12: The Post-Dalradian Strata Along the North-West Coast of Lough Foyle, Inishowen, Co. Donegal. By T. Murphy, D. G. G. Young and P. M. Brück. Pp. 171-182+ plate 7. 20p. Vol. 71, Section B, No. 13: The Present Distribution of the Bank Vole Clethrionomys glareolus. Schreber in Ireland. By J. S. Fairley. Pp. 183-190. 12p. (Dublin:
Royal Xrish Academy, 1971.)

(2510 Sixteenth Annual Report 1971. Pp. 58. (Sheffield: The British Glass Industry Research Association, 1971.) Porifera together with Archaeocyatha. Compiled by S. Ware. Pp. 18. 75p. 1968, Vol, 105, Section 9 Mollusca. Compiled by the Staff of the Zoologica Society of London. Pp. 165. £3. 1968, Vol. 105 Section 19: Mammalia. Compiled by the Staff of the Zoological Society of London. Pp. 554. £12. 1969 . Browning. Pp. 106. 66.50.

Department of Education and Science. Statistics of Department of Education and Science. Statistics of Education 1970. Vol. 1: Schools. Pp. xv +79. (LonNatural Environment Research Council. National Institute of Oceanography, Collected Reprints, Vol. 18. Reprints 725-777. (Godalming, Surrey: National Institute of Oceanography, 1971.)

Imperial College of Science and Technology (University of London). Calendar 1971-72. Pp. xi +619 . Imperial College-Royal College of Science, 1968-71 Research Report. Pp. iv +178 . (London: Imperial
[2810 College of Science and Technology, 1971.) Institute of Rheumatology. Third Annual Report, 1969. Pp. 53. Fourth Annual Report, 1970. Pp. 68. (London: The Mathilda and Terence Kennedy Institute of Rheumatology, 1971.)

Philosophical Transactions of the Royal Society of London. A: Mathematical and Physical Sciences. Vol. 270, No. 1206: A Discussion on Ocean Currents and their Dynamics. Organized by G. E. R'. Deacon,
FRS. Pp. 349-465 + plate 12. (London: The Royal FRS. Pp. 349-465+ plate 12. (London: The Royal
Society, 1971.) $£ 3.10 ; \$ 8.10$. Bulletin of the British Museum (Natural History). Entomology, Vol. 26, No. 4: Revisional Notes of African Charaxes (Lepidoptera: Nymphalidae), Part VII. By V.G. L. van Somercn. Pp. $181-226+11$ plates. £3.80. Vol. 26, No. 5: A Revision of the African Genus Phylloxiphia Rothschild and A P P $227-243+11$ plates. $£ 1.60$. (London: British Building Research Station Digest, No. 135 : Motorway Noise and
HMSO, 1971.) $5 \mathrm{p}$.
Royal Observatory Bulletins. No. 160: Results Obtained with a Danjon Astrolabe at Herstmonceux. II. Analysis and Discussion: Herstmonceux Astrolabe Catalogue. By D. V. Thomas and R. E.
Wallis. Pp. 113-172. 85p net. No, 161: Rhw Wallis. Pp. 113-172. 85p net. No. 161: Rhw V. M. Clube, Z. Aslan, T. W. Russo and E. D of Ao Stars Perpendicular to the Galactic Plane IV. Racial Velocities in the South Galactic Cap. IV. Racial Velocities in the South Galactic Cap. Haslam, Pp. 259-271. 25p net. (Herstmonceux Fabian Research Series, No. 297: Fair Deal for Fabian Research Series, No. 297: Fair Deal for
Householders. By Della Adam Nevitt. Pp. 32. 25p Houscholders. By Della Adam Nevitt. Pp. 32. 25 p 1971. Pp. 16. (London: Fabian Society, 1971.) [911 Agricultural Research Institute of Northern Ireland. Forty-fourth Annual Report, 1970/1971 Pp. 38. (Hillsborough, Co. Down: Agricultura Department of Education and Science. Keeping Animals in Schools: a Handbook for Teachers. Pp. xi+74. (London: HMSO, 1971.) 50p net. 1911 Building Research Station Current Paper 29/71
Strain Measurements at the GPO Tower, London By K. J. Eaton and J. R. Mayne. Pp. 8. (Reprinted from Strain, Vol. 7. No. 3, July 1971.) (Garston: Building Research Station, 1971.) gratis. [911 Engineering Industry Training Board. Report and Accounts 1970-71. Pp. 114. (London: Engineering
Industry Training Board, 1971.) Andustry Training Board, 1971.)

British Steel Corporation. Steelresearch 71: Progress Report on BSC Research and 1971.) 54. (London: British Steel Corporation The Future of Brassica Fodder Crops. (Proceed ings of a Discussion Meeting held at the Rowett Research Institute, Aberdeen, on 11 June 1971. Pdited 67. (Bucksburn, Aberdeen: The Rowett RePp. 67 (Bucksburn, Aberde

Building Research Station Current Paper 10/71 Employment Expansion and the Development of New Town Hinteriands 1961-1966. By A. A. Ogilvy. Pp. 13. (Garston, Watford: Building Research Station, 1971.) raphical Series No. 797: Some References on Perpetual Motion, 1558-1965. Pp. 4. (London Science Museum Library, 1971.) Morphology and International Journal of Insect Morphology and
. Embryology, Vol. 1, No, 1, September 104. Published quarterly. Annual Subscription Rates: For libraries, research establishments, an all other multiple-reader institutions: $£ 12 ; \$ 30$. Private individuals, whose departmental libraries subscribe, may obtain this journal for their persona use at a reduced rate of $£ 5, \$ 12$. (Oxford, and
Elmsford, NY: Pergamon Press, 1971.) [1311

\section{Other Countries}

Fisheries Research Board of Canada. Technica Report No. 272: PCB and Other Industrial Halogenated Hydrocarbons in the Environment. By V
Zitko and P. M. K. Choi. Pp. S5. (St. Andrews NB: Fisheries Research Board of Canada, Biologica. Station, 1971.)
US Department of the Interior: Geological Survey. Water-Supply Paper 1899-E: Ground Water Central Minnesota. Pp. iii $+24+2$ piates. WaterSupply Paper 1906: Surface Water Supply of the United States 1961-65. Part 2: South Atlantic Slope and Eastern Gulf of Mexico Basins. Vol. 3: Basins from Apalachicola River to Pearl River. Pp. ix + 774 t plate 1. (Washington, DC: Government Printing Office, 1970 and 1971.) [1910 New Zealand Meteorological Scrvice. Meteorological Observations for 1968-Stations in New Zealand and Outlying lslands, including the Cook 1969 Stations in New Zealand and Outlying 196. including the Cook Group. Pp. 73. Rainfall Obser vations for 1969 ... Stations in New Zealand and Outlying lslands, including the Cook Group. Pp. United States Geological Survey. Water-Supply Paper 1999-K: Analysis of Stream-Temperature Variations in the Upper Delaware River Basin, New ington, DC: Government Printing Office, 1971 .) $\$ 0.30$.

Smithsonian Contributions to Zoology. No. 93 Notes on Neotropical Mesostigmata VI: Four New Venezuclan Species of the Genus Periglischrus Allison and R. Antequera. Pp. 16. (Washington. DC: Smithsonian Institution Press, 1971. For salc Background Study for the Science Council of Canada Background Study for the Science Council of Canada No. 18: From Formalin to Fortran-Basic Biology in
Canada. By P. A. Larkin and W. J. D. Stephen. Pp. Canada. By P. A. Larkin and W. J. D. Stephen. Pp. Journal of Molecular Evolution, Vol. 1, No. 1, 1971 Pp. 1-114. 136 DM per volume (four issues). (Berlin Unew York: Springer-Verlag, 1971.) No. 11 : So Unesco. Natural Resources Research No. 11 : Soils and Tropical Weathering-Proceedings of the Bandun Symposium, 16 to 23 November 1969 . Pp. 149. (Paris:
Unesco, 1971.) 30 francs; $£ 2.25 ; \$ 7.50$. Unesco, 197.) Records of the Australian Museum, Vol. 28, No. (26 August 1971): Intertidal Alcyonarians in the By Huzio Utinomi. Pp. 87-110 + plates 15 and 16. By Huzio Utinomi. Pp. 87-110 +plates \$1. and 12610 (Sydney: The Australian Museum, Australian Museum Annual Report of the Western Australian Museum
1969-70. Pp. 44. (Perth: Western Australian Museum, 1969-70. Pp. 44. (Perth: Western Australian Museum, Geological Survey of Western Australia. Annual Report for the year 1970. Pp. $74+34$ plates. Bulletin 121: Devonian Corals from the Canning Basin Western Australia. By (Porth: Geological Survey of
Pp. 158 (20 plates). (Per:
[2810 Canada: Department of Energy, Mines and Resources. Paper 70-17: Metallic Mineral Industry, District of Mackenzie, Northwest Territories. By Brock River Map-Area, District of Mackenzie (97D). Brock River Map-Area, District of Mackenzie By H. R. Balkwill and C. J. Yorath. Pp. v+25. $\$ 2$.
Paper 70-56: Bedrock Topography, Buried Valleys and Nature of the Drift, Virden Map-Area, Manitoba. By R. W. Klassen and . E. Wyder. Pp. 1971) 2910

\section{HOW TO BUY NATURE}

Volumes start in January, March, May, July, September and November, but subscriptions may begin at any time.

The direct postal price per subscription is :

12 MONTHS * (52 issues per title)

$\begin{array}{lcc} & \begin{array}{c}\text { Surface Mail } \\ \text { UK and } \\ \text { worldwide }\end{array} & \begin{array}{c}\text { Airfreight } \\ \text { U.S.A. \& Canada }\end{array} \\ \text { Nature (Friday) } & £ 14 & \$ 48 \\ \text { Nature + } & & \\ \text { Nature Physical Science } & £ 24 & \$ 83 \\ \text { Nature + } & & \\ \text { Nature New Biology } & £ 24 & \$ 83 \\ \text { All three editions } & £ 29.50 & \$ 108 \\ \text { Annual Index } & £ 1 & \$ 3\end{array}$

- Rates for shorter periods pro rata (minimum three months) (Charge for delivery by air mail on application)
Editorial and Publishing Offices of NATURE

MACMILLAN JOURNALS LIMITED

4 LITTLE ESSEX STREET, LONDON WC2R 3LF

Tolephone Number: 01-836 6633. Telegrams: Phusis London WC2R 3LF Telex: 262024

711 NATIONAL PRESS BUILDING WASHINGTON DC 20004

Telephone Number : 202-737 2355. Telex : 64280 Subscription Department

MACMILLAN JOURNALS LIMITED

BRUNEL ROAD, BASINGSTOKE, HANTS

Telephone Number : Basingstoke 29242

American display advertisements

NATURE SCIENTIFIC PUBLICATIONS INC

711 NATIONAL PRESS BUILDING WASHINGTON DC 20004

All other advertisements

T. G. SCOTT \& SON, LIMITED

1 CLEMENT'S INN, LONDON WC2A 2ED

Telephone 01-242 6264/01-405 4743

Tolegrams: Textualist London WC2A 2ED

Registered as a newspaper at the Post Office

Copyright (C) Macmillan Journals Limited, December 311971 